\title{
"Notorious RBG": A conversation with United States Supreme Court Justice Ruth Bader Ginsburg
}

\author{
Ruth Rubio-Marín*
}

On February 2, 2016, Prof. Ruth Rubio-Marín, Chair of Constitutional and Comparative Public Law at the European University Institute (EUI), interviewed the U.S. Supreme Court Associate Justice Ruth Bader Ginsburg. The interview took place in the framework of the European University Institute's annual Ursula Hirschmann Lecture, a space dedicated to stimulate research and thinking which links ideas about Europe and the study of gender. Justice Ruth Bader Ginsburg engaged in a conversation that tackled her whole persona, without making rigid divides between the professional and the personal. Deep legal analysis, personal anecdotes, and invaluable advice for future researchers and lawyers intertwine in the interview, which sheds light on important dimensions of equality law.

Ruth Rubio-MaRín: Good afternoon, dear researchers, dear colleagues, and dear guests. It is really a great honor to have such an extraordinary guest for this annual Ursula Hirschmann lecture. When we invited her, two years ago-because she is tough to get, believe me - she said she preferred a dialogue, a conversation, or an interview, over a formal lecture. This was a brilliant suggestion because it allows us to tackle today the whole persona without making rigid divides between the personal, and the professional, as good feminists, I would say. And I think this is something particularly important for our researchers, whom I want to invite to be the main protagonists of this event, as they face, in the years to come, the question of how to juggle the ambitious professional careers - that I am sure most of them want to have-with fulfilling personal projects.

So, maybe to get us started. Justice Ginsburg, how does it feel to become, at this stage in your life, this famous character with your image on T-shirts, fingernails, mugs, and tattoos? And what do you think it is an expression of?

* Professor of Constitutional Law, University of Seville. Email: rrubio@us.es. The present interview is also available as video recording at https://www.youtube.com/watch? $\mathrm{v}=\mathrm{qRqe} 43 \mathrm{iwhbw}$. 
Justice Ruth BADER GinsBurg: In the words the current generation uses: "it's awesome!” It is quite unbelievable that, although I am nearly 83, everyone wants to take a photograph with me. The book ${ }^{1}$ was sparked by a second year student at NYU Law School. She was upset about a decision the United States Supreme Court had just rendered. The case is known as Shelby County. ${ }^{2}$ The majority opinion in Shelby County essentially put an end to the Voting Rights Act of 1965, a civil rights law designed to make sure African Americans would not be deprived of the franchise. The NYU student was angry, but she understood that anger is not a useful emotion. So, she decided to do something positive. She created a Tumblr and launched it with my dissenting opinion in the Shelby County case. And it took off from there. Now, why is the younger generation interested in an octogenarian like me? Well, one thing the Shelby County dissent illustrated is that one can disagree without being disagreeable and one can be effective by avoiding invectives and, instead, employing reasoned responses. So, that's how the Notorious RBG began. The name comes from a well-known, now deceased, rapperNotorious B.I.G. When I was told this, I said we had something in common: both the rapper and I were born and bred in Brooklyn, New York. As for the mugs, and the t-shirts: that is fine. But the tattoo is a bit too much.

RRM: So, when you attended law school, the world was different from the world our researchers and especially our female researchers are living in. Can you tell us a little bit more about the world back then, when you were a young woman and a young mother, with ambitions for your professional career? This will allow us to put the rest of the conversation into perspective.

RBG: Harvard Law School did not admit women until the Fall of 1950. I entered law school in 1956. There was a famous dinner held by the Dean of the Law School for all of the women in the entering class - all nine of us, in a class of over 500-in which he asked each of us, in turn, to explain why we were at the Harvard Law School occupying a seat that could be held by a man. Years later, I came to know the Dean quite well. I understood that he was a man not known for his sense of humor. He did not ask the question to wound or offend. It was 1956, just six years after women were first admitted to Harvard Law School, and some members of the faculty still thought it was unwise to admit women. The Dean wanted to be armed with stories by the women themselves about what they expected to do with a law degree.

There were nine of us. The class was divided into four sections. There were two, at most three, women in any one section. We felt a special obligation. If we were called on in class, we felt that we were representing all women. If we gave a dumb answer, the response might have been: "What do you expect of a woman!" So we were always well prepared. The difference between the 1950s and the 1970s was well expressed by a colleague of mine on the faculty of Columbia Law School. By that time, the 1970s, women were about 25 percent of Columbia Law students - today they are about 50 
percent. The professor confessed a certain longing for the old days. When the class was moving slowly, he explained, and he wanted to elicit a crisp right answer, he would call on a woman. She was always prepared, she would give the right answer, and he could move forward with the class. Nowadays, he lamented, there is no difference: The women are as unprepared as the men!

In the 1950s, there was no anti-discrimination in employment law. Law firms would post sign-up-sheets for student interviews. Often, they would be headed "Men only." Justice Sandra Day O'Connor had graduated from Stanford Law School at the top of her class, but no law firm in the State of California would hire her to be a lawyer ... to be a secretary, yes, but not a lawyer! So, to get her first job, she went to a county attorney and said: "I will work for you for free, for four months. Then you can decide whether my work is valuable enough to put me on the payroll." That's how life was for women aspiring to be lawyers in the 1950s. Not much had changed by 1963, the year I started teaching law. My first class, at Rutgers Law School, had a hundred students. Only three were women. Across the country, the situation was the same. Some 3 percent of all law students were women. The change in the law school world in recent decades has been enormous. Perhaps I can illustrate it best by pointing out that my dear colleague, Elena Kagan, was the Dean of the Harvard Law School. When she left Harvard to become Solicitor General of the United States, she was succeeded by another woman, Martha Minow. A university which was once all male and now has a woman president. So, I have seen, in my lifetime, great changes.

RRM: So coming to today and referring to another eminent woman I am sure you know of, Professor Anne-Marie Slaughter, Professor of Politics and International Affairs at Princeton University. Anne-Marie Slaughter wrote a rather controversial, but much-read piece for the Atlantic Magazine. This piece was called "Why women can't still have it all." ${ }^{3}$ In fact, in spite of the negative sounding title, I really recommend you all to read it: it is full of good advice, especially for women seeking to navigate the demands of family life and professional life. Anyways, the original piece was written by professor Slaughter as she was stepping down from two years of servicebetween 2009 and 2011 —after being the first woman director of policy planning for the US Department of State. She was returning to Princeton, after two years in Washington, because she found it impossible to juggle the demands of a teenage boy and the job she had to do, in spite of the fact that the primary caretaker in those two years had been her husband, also a Princeton professor. She started writing about her experience because she felt there was an obligation, on the part of successful women, to actually be honest about the fact that, although a few women, a few heroines, a few super women, like yourself — and she cites you explicitly because you were an inspiration to her-made it, if successful women go around saying that women can have it all, they deny the statistics that say that most women —in today's America still-actually can't have it all. Denying it, she claims, is not good because it conveys to women 
the message that it is their fault if they cannot have it all and that they could if they were just willing to put in that extra-effort. This then avoids a conversation about the structural changes that actually need to take place for most women to be able to have more balanced work and family life. So, let me ask you, can women have it all?

RBG: First, Anne-Marie Slaughter's article is now a book. ${ }^{4}$ There is another book of advice about how to be a professional woman and a parent. The author is a law professor at Yale, Amy Chua. She titled her book "Tiger Mom." 5 To be honest, I was a bit surprised that Anne-Marie Slaughter complained that a woman cannot have it all. I do not know anyone, man or woman, who has it all at once. True, in my relatively long life, I have had it all, but not all at the same time. For example, there were the years when my husband, as a young lawyer, was determined to become a partner in a New York law firm within five years. During those years, I took primary responsibility for my (then) one child and the household. When the women's movement came alive, in the late 1960s, and I co-founded the ACLU [American Civil Liberties Union] Women's Rights Project, my husband realized I was doing something more important than the tax problems he was solving for big corporations and rich individuals. So, it was natural for us to shift roles at home.

I must thank my daughter for her part in getting me out of the kitchen. My routine had been the following: I came home after a day's teaching, and took out the only cookbook I used. It was titled "The Sixty Minutes Chef." No recipe took longer than one hour, from the time you walked in the door until dinner was on the table. My husband was a master chef and my daughter, in her high school years, noticed the huge difference between Mommy's cooking, and Daddy's, and decided Mommy should be phased out of the kitchen entirely. And so I was: from 1980s to now, I have not cooked a meal. How could I manage, when my husband died, six years ago? My food-loving daughter visits once a month to cook for me. She fills the freezer with meals individually packaged and, the next day, goes back to Columbia Law School where she teaches. It is very nice to have her with me once a month. She is an excellent cook, almost as good as her father.

Anne Marie Slaughter describes her son as being a bit of a problem, meaning he was not doing well in school. I too had a son who was called "lively" by his teachers. In fact, I called him "lively," they called him "hyperactive." Anne-Marie Slaughter relates that when she went back to Princeton-where she is not just teaching, but is also Head of the Woodrow Wilson School and lectures across the country-her child notably improved. In real life, that does not happen. With my son, who is today a grand human, there was no quick change in his behavior in his high school years. It took quite a long time for him to channel his energy successfully. So I am a little suspicious about the notion that a mother's presence at home can bring about an immediate transformation in her child's behavior. 
The main thing I would like to convey is that, for all of us, we will not have it all at one time. I have been blessed by the course of my life. If you have a life partner, it is always a balance between the two of you. Sometimes, it is one that helps the other, and, at other times, it shifts. When I got my first good job in Washington DC, in 1980, thanks to President Jimmy Carter, ${ }^{6}$ people asked me "Isn't it difficult to commute from New York to Washington DC?” My response: "Why do you think I am commuting?" The assumption was that my husband, a partner in a New York law firm, would have remained in New York. But he did not remain in New York. We moved together to Washington DC, and he became a distinguished professor of tax law at Georgetown University Law Center. At that time, appointments of women to the federal judiciary were still unusual. We would go to social functions, and, when Judge Ginsburg was introduced, the hand first shaken was often my husband's, who politely explained that he was not Judge Ginsburg, I was.

RRM: You are known to have said that choosing the right life partner is probably one of the wisest career decisions that women make. In fact, your husband Marty, with whom you shared, I think, 56 years of a beautiful marriage and who had a successful career as a tax lawyer, is known to have said that the most important professional thing he has done was support you. This is quite extraordinary. How was it for him, as a man, to be in the role that was traditionally fulfilled by the wives of the Justices of the Supreme Court? What does it take for a man to be able to do that?

RBG: It takes complete confidence in his own ability. In days when we were very young - we met when I was 17 and he was 18-he was the only boy I knew up to that time who cared that I had a brain. Marty must have thought I was someone special, why else would he decide he wanted to spend the rest of his life with me. When we were both law school students (Marty in his second year, I, in my first), Marty boasted that his wife's grades would gain her a place on the law review. And, as it turned out, they did. Marty always made me feel I could do whatever I aspired to do. I will tell you one story from the early 1970s about sharing responsibility. I mentioned this lively son of ours. When he was in grade school, I was called at least once a month by the headmaster, or a teacher, or the school psychologist. The message: "Come at once to discuss your son's latest misadventure.” One day, I was at my office at Columbia and was really tired - I had stayed up all night writing a brief. When I got the familiar call, I said to the headmaster: "This child has two parents. Please alternate calls. And today, it is his father's turn." So Marty left work to see the headmaster. What had our son done this time? He had stolen the elevator, a stone-faced teacher told Marty. It was a hand-operated elevator, the operator had gone out for a cigarette, and one of my son's classmates had dared him to take the elevator, filled with kindergarteners, from the ground floor to the top floor. When he got to the top floor, he was met by the headmaster. Informed that our son stole the elevator, Marty responded: "How far could he take

6 President Carter, in 1980, appointed then Professor Ruth Bader Ginsburg to the United States Court of Appeals for the District of Columbia Circuit. 
it?" Well, neither Marty's sense of humor, nor the request that the school alternate calls, brought about any rapid change in our son's deportment. But from then on, calls came barely once a semester. There was much more reluctance to take a man away from his work than to call on a woman to account for the misbehavior of her child.

RRM: So, you were blessed to find a supportive partner. Not every woman is. Also, many of us think, and I am sure you agree, that this is not enough, that, ultimately, we should aspire to have a society, a community, a state, which takes its due responsibility in enabling reproduction, that is, a care-friendly society. In your writings, you have been very careful to stress the idea that, in order to achieve that, it is not necessarily a good way to give extra accommodations for working women, because they can backfire-for example, they can in fact stigmatize women or make employers hire less of them - and so you have defended gender neutral solutions. Just to give you a concrete example of what I mean by gender neutral solutions, in the United States, under the Family and Medical Leave Act of 1993, any employee can take up to twelve weeks of unpaid leave, to either take care of a new-born, or a sick family member, or themselves, when they are sick. And precisely because the statute is formulated in a gender-neutral way, it was upheld by the Supreme Court. Now, many of us think about whether this is the way to go: firstly, should we be assimilating having a child with being sick - does it not pathologize and stigmatize pregnancy and child-rearing; secondly, the leave is unpaid — which is most unfortunate. So, in Europe — as you knowwe have a mandatory minimum of fourteen weeks of paid maternity-some of which is actually compulsory leave. It is a very different solution from the arrangement in the United States, and a solution which is justified as giving equal opportunity to working mothers, though one can argue that it is a solution that also entrenches rather than subverts gender stereotypes and gender roles. In fact, in Europe, we do have many more women working part-time, as a solution to working and mothering, than men. So, my question to you is: can we really think of a third way, a solution that grants pregnancy and parenting, both for men and women, specific recognition and accommodation, without producing gender stereotypes? In Europe, we are barely starting to experiment with some other formulas - such as fathers' leaves, until now usually very short and not mandatory or gender-neutral parental leaves with incentives for fathers to take them. Do you see a third way between what the United States and Europe have done so far, a way of granting care and reproduction more centrality as a shared social good without entrenching gender roles that limit women's autonomy?

RBG: You asked a question that has many subparts. Perhaps, I should say first a word about the background of social legislation. Social legislation has been common in Europe for a long time, since Bismarck at least. In the United States, the attitude has been fierce individualism: "We do not need the State to help. If you have the opportunity, and you are ready to work hard, you do not need the government's help." We did not get social security in the United States until the 1930s, and the official title of our social security law is the Federal Insurance Contributions Act-insurance contributions. 
The Act was sold to the public not as social welfare legislation, but as an earned right: "If you work, you get insurance as a result of your contributions."

I am puzzled when people sometimes say "You are an assimilationist as opposed to accommodationist" when they see me defending gender-neutral arrangements instead of encouraging arrangements targeting women's needs specifically. If a label is wanted, I would call myself a pragmatist, dealing with the art of the possible. When I began litigating gender discrimination cases, the law books - federal and statewere riddled with gender-based differentials. The overall picture was that of separate spheres: the paid work sphere for men, the home and child care sphere for women. If the woman worked, she was just a pin money earner. That separate spheres view of the world was harmful to women, and our effort was to break it down, to end lawenforced separate spheres, for men as well as women. A popular periodical for girls and young women, launched in the 1970s, was Ms. Magazine. Ms. produced a record for children. The first song was "Free to Be You and Me." The message was simply this: Wherever you go, whatever your God-given talent, you should not be held back by artificial barriers. The next song was "William has a Doll": It was ok for a boy to care for a doll. That's what we were trying to do: break down the separate-spheres-andgender-roles mentality.

As for the Family and Medical Leave Act, which was passed in the 1990s, that law was written with women workers in mind and reflects what a woman worker needs. She needs to be protected against being fired and losing her job if she has to stay home to care for a sick spouse, a sick child, a sick parent, or if she herself is sick. True, the Act has many shortcomings, most glaring, the leave is unpaid. But it was a beginning. I see the Family Medical Leave Act as woman-worker centered law, not a law designed for male workers with women's needs out of sight. The Act is quite different from the law involved in the social security cases I was litigating. Typical of that social-security law, when a man died, there were benefits for his wife, but when a woman worker died, there was nothing for the man who was her spouse.

RRM: Can you tell us some more about those cases that you litigated in the 1970s?

RBG: Of all the cases that I litigated in the 1970s, my favorite was Stephen Wiesenfeld's case. ${ }^{7}$ Stephen was a man whose wife had been the principal earner in the family, while he stayed mainly at home, starting up a computer service business and attending to household chores. His wife had a healthy pregnancy — she was teaching school until the ninth month-when she went to the hospital to give birth. The doctor came from the delivery room to tell Stephen Wiesenfeld he had had a healthy baby boy, but his wife had died of an embolism. Stephen was determined to work only part-time until his child was in school full-time. So he went to the social security office to register for what he thought were childcare benefits, but was told that those benefits were available only to women. He wrote a letter to his local newspaper, describing how and why he had been denied 
childcare benefits. The tagline of his letter: "Does Gloria Steinem-a leading feminist in the United States-know about this?" It happened that a woman who taught in the Spanish department at Rutgers read Stephen's letter, and thought what happened to him was not right. She suggested that he contact the ACLU. Wiesenfeld's case was ultimately taken up by the Supreme Court, which rendered a unanimous judgment in his favor. The majority thought the discrimination was against women as wage earners, because women's work did not produce for their families the same benefits a man's work would yield. Justice Stevens thought that the law discriminated against men as parents, because they were not given the same opportunity a woman would have to care personally for a child. And one, who later became my chief justice — he was then Justice Rehnquist — thought the law was arbitrary from the point of view of the baby: Why should the baby have the opportunity to receive the personal care of a parent only if the parent is female? A perfect example of how the separate spheres notion hindered everyone: the woman worker, the man as a parent, and the child. That's what the 1970s litigation was about. It endeavored to overturn laws that pigeonholed people solely because they are women or men.

In that regard, let me describe a 1982 case in which the Court's opinion was written by Justice O'Connor, the very first woman appointed to the US Supreme Court's bench. It is titled Mississippi University for Women v. Hogan. ${ }^{8}$ The plaintiff was a young man who wanted to go to what was the best nursing school in his area, but Mississippi's school admitted only women. When his case got to the Supreme Court, a minority of the Justices saw reserving the nursing school for women as a form of affirmative action for women. Justice O'Connor, who grew up as a woman, understood that there could be no better aid for women in the nursing profession than to get men into that profession in numbers. When a field is dominated by women, pay tends to be low. Get men to do the same job, and the pay rate tends to go up. Keeping the school for women only could not be genuine affirmative action for women. Women would be well served if nursing schools were open to men. The more men entering that profession, the better off women in nursing would be.

RRM: Let me maybe, now, talk about something in which American and European constitutionalism differ also, which is abortion constitutionalism. What is interesting is that, in the 1970s, both in Europe and in the United States, we saw courts stepping in vis-à-vis the legislator, to decide what was possible or not in terms of legislation. The starting positions of courts on both sides of the Atlantic were for the most part radically different. In Europe, to the extent, which was not always the case, that Constitutional Courts took up the question, the best example being the 1975 abortion decision of the German Bundesverfassungsgericht, the starting point in the constitutional reasoning was the respect due to the life of the unborn which was almost automatically translated into a constitutional duty of motherhood falling to the pregnant woman. Now, of course, you know that the US Supreme Court started from a very different perspective, when, in Roe $v$. Wade, ${ }^{9}$ it decided that women, on the advice of 
their doctors, had a privacy-based right to decide whether to carry through with their pregnancies, upholding a trimester framework. So, for Europeans, and European feminists, Roe v. Wade has always stood as a symbol of the utmost recognition of women's reproductive autonomy. Now, you have actually been rather critical of Roe v. Wade, and I was wondering whether you could share with us why you were so unconvinced by this decision.

RBG: Not by the judgment. The judgment in Roe $v$. Wade was in my mind absolutely right. The Texas law in question was unconstitutional. But as you know, the United States is a federal union, and abortion law was state law, not federal law. States were all over the lot at the time Roe v. Wade was before the US Supreme Court. In some states, like my home state, New York, a woman could have an abortion in the first trimester if she wanted it, no questions asked. Other states specified grounds on which an abortion was permitted, including whether bearing a child would place the woman's health at risk, or whether there was a danger of a deformed fetus. And then there was Texas. Texas allowed abortion only if it was necessary to save the woman's life. Her health could be devastated; it did not matter. It was the most extreme law in the nation, and the Court easily could have said that this most extreme law was unconstitutional. Instead, the Court wrote a sweeping opinion that made every law in the country, even the most liberal, unconstitutional. My notion was that, if the Supreme Court had simply invalidated the most extreme law, then the usual political process would have worked. There would have been reactions in other States and challenges to other restrictive rules such as requiring the approval of two doctors, or having the abortion performed in a hospital. The Court did not progress step-by-step through a series of decisions, as it usually does. Instead, the Court's decision did it all. The people who opposed women's access to abortion gained a single target, Roe v. Wade, to organize against. There was a strong anti-abortion movement before Roe v. Wade, but it accelerated after that decision. Opponents could rally around a decision, Roe v. Wade, made by an undemocratic institution, nine lifetime appointees. Every year - this year, shortly before I came to Florence-there is, in Washington, DC, a "march for life" on the anniversary of Roe v. Wade. I repeat, the judgment striking down the Texas law was absolutely right. But the Court's opinion, in my view, was not satisfactory. In addition to going too far too fast, the opinion was as much about a doctor's right to practice medicine as it was about a woman's right to control her own destiny. And the decision rested on privacy. But it is a woman's autonomy and equality, not her privacy, that is at stake: it is her equal right to decide what her life's course should be. We continue to have abortion business, including an important case this very Term. The case again involves the State of Texas, which had some forty clinics that offered contraceptive and abortion services. That number would shrink to around eight under a newly enacted Texas law. Why? That law requires any facility offering abortions to meet all the standards set for ambulatory surgical centers. Also, to perform abortions, a physician must have privileges at a hospital within thirty miles from the clinic. No such requirements apply to birthing centers, although childbirth is riskier than an 
early stage abortion. The Texas law has been challenged, and the case will be argued at the end of February.

RRM: Too much, too fast. I wonder whether some voices would say the same thing about the Obergefell same-sex marriage decision. ${ }^{10}$ In other words, when does a Supreme Court justice feel and know when it is the right time to act? Is the role of the judge to reflect, or to change values that are socially dominant?

RBG: The judiciary is a reactive institution. Judges do not decide "this is the year we are going to end segregation in public schools," or "this is the year we are going to take care of abortion." We react to the cases brought before us. Let's look at one of the most famous cases the Court ever decided: Brown v. Board of Education. ${ }^{11}$ Some people think Brown was a bold step for the Court to take: essentially to spell the end of apartheid in America. But preceding Brown v. Board, there was World War II, a war against odious racism. And yet our own troops, in that war, were segregated. It was not until the very end of the war that troops began to be integrated. When Brown v. Board came to the Court, a brief was filed on behalf of the US Government. Essentially, this is what it said: "The United States has been embarrassed all over the world because the Soviet Union is constantly playing up the racism that exists in our country. Please put an end to it, so that the Soviet Union can no longer say to other countries, don't look up to the United States as a model, because it is a racist society.” The US Government asked the Court to end law-enforced separation of the races in school. So it was not that hard for the Court to make the decision it made. Building blocks were in place, a series of decisions finding separate facilities, in fact, were not equal.

There has been, I think, an enormous change in the United States in the attitude toward gay, lesbian, and transgender people. In part, it is generational. It is not an issue for young people - at least not the young people I encounter. For them, it is simple. If you love someone, and you want to marry that person, it should not matter whether she is of the same or the opposite sex. What happened to transform attitudes in the United States? People who are gay or lesbian stopped hiding in the closet. A fine Supreme Court Justice, Justice Powell, once said he had never had a gay law clerk in his chambers. In truth, he had had a number, but they were still in the closet. When people stood up and said, "I am gay," others looked around and realized they were their child's best friend, their colleague. That realization made others change their thinking. The first Chief Justice under whom I served is an example. In the 1970s, if you had asked then-Justice Rehnquist a question about fair treatment of gay and lesbian people, he might have said: "no law requires it". By the 1990s, he had hired as his assistant a woman whose partner was another woman. Together they were raising two children, together they were attending Court functions. Attitudes changed. It happened swiftly. But what it took was people willing to say "this is who I am and it is ok." There have been a few county clerks who resisted giving marriage licenses to

10 Obergefell v. Hodges, 576 U.S. (2015).

11 Brown v. Board of Education, 347 U.S. 483 (1954). 
same-sex couples. But for the most part, there has been no fuss, no rebellion against the Obergefell decision.

RRM: Justice Ginsburg, when asked when there will be enough women at the Supreme Court of the United States, you are known to have answered: "when there are nine of us!," which, I think, is brilliant, for, as you have said, for the longest time there was a male-only bench and no one seemed to have any concern about its legitimacy. You described your feeling when Justice O'Connor retired as one of loneliness, and you have celebrated Justices Sotomayor and Kagan joining the Court so that women are now sitting all over the bench, you near the middle reflecting seniority. Can you tell us a little bit more about why exactly you think it is important to have women sitting at the Court? Is it that they bring different experiences? Is it that having women sitting at the table generates different dynamics, even in the way affairs are discussed? Is it the importance of role models for the younger generations? What is it?

RBG: All of the above. I would put first, the public perception. When Justice O'Connor left the Court, and I was the lone woman, when we emerged from the velvet burgundy curtains to take our seats on the bench, the public would see a small woman, and eight taller well-fed men. It was altogether the wrong image. Now, because I have been there so long (nearly twenty-three years), I sit toward the middle. At one end, there is Justice Kagan, at the other, Justice Sotomayor. School children who visit the Court find that women are one-third of the bench. We are no longer one-at-a-time curiosities. If you attend an oral argument at the Court, you will see that my newest colleagues are not shrinking violets. They are very active in questioning counsel at oral arguments. In fact, Justice Sotomayor rivals Justice Scalia in asking the most questions at oral argument.

Does it make a difference? On some issues. We all come to our jobs with whatever upbringing we have had and who we are. Growing up female is not the same as growing up male. I recall one case where my colleagues listened and learned during the oral argument. The case was about a thirteen-year-old girl who had been strip-searched because she was reported to have had illegal pills in school. (The pills turned out to be a nonprescription headache remedy, sold over the counter.) The girl under suspicion was removed from a classroom and strip-searched in the girls' bathroom. Her mother was outraged and sued the school district for exposing her daughter to that humiliation. At the oral argument, there were comments about boys changing clothes in the locker room and nobody thinking that was a problem. I said, from the bench, that a thirteen-year-old girl is not like a thirteen-year-old boy in that regard. She is very self-conscious about her body and can be hugely embarrassed by being exposed, unclothed, to a teacher. The jokes stopped, no one spoke about boys in the locker room anymore. Everyone took it seriously. Some of my colleagues have daughters, so they understood the difference between thirteen-year-old boys and girls of that age.

There have been other incidents concerning the way the Court runs. A journalist who wrote an advice column, and was known as Dear Abby, received a letter from a woman who came to the Supreme Court with her husband to attend an argument. 
She came early to be sure she would be seated. She had breakfast in the cafeteria and decided to use the women's restroom after her husband returned from the men's room. She was told by a police officer: "I am sorry, but the women's restroom does not open until 9 o'clock." Dear Abby forwarded the woman's letter to Justice O'Connor and me, asking whether the report was true. Indeed, it was. The time for opening the women's restroom was set in days when very few women appeared at the Supreme Court. Next day, there was no delay in opening the women's bathroom.

We have had states - the State of Minnesota, for example-with a Supreme Court composed of five women, that is, every member was a woman. Our Court is not doing as well as the Supreme Court of Canada, also a nine-member court. Four women occupy seats in that court. One of them is the chief justice. I think women in numbers are there to stay, not just on the Supreme Court bench, but in state and federal courts across the country. The change came in the late 1970s, during President Jimmy Carter's term in office. Carter was not a lawyer, but he cared about the justice system. He looked at the federal bench and observed: "These guys all look like me, but that's not how the great United States looks!" He was determined to appoint women and racial minority group members in numbers. Although he had only four years in office and no Supreme Court vacancy to fill, he literally changed the face of the US judiciary. He appointed over twenty-five women to federal trial courts and eleven women to federal appellate courts - I was one of the lucky eleven. President Reagan did not want to be outdone. He was determined to appoint the first woman to the Supreme Court.

So, large changes in a few years. When I attended law school, there were no women on the law faculty. As an undergraduate, I had gone to a university-Cornell University - where there was a four-to-one ratio-four men to every woman. The excuse for the ratio: Women had to live in dormitories, but men could find accommodations off campus, in college town rooms, or apartments. They did not have to reside in a dormitory. At Harvard Law School-by the time I enrolled, I was married and the parent of a fourteen-month-old daughter, so the residence-hall policy did not affect me- there was no room in the dormitories for women. The dormitories were reserved for men, and women had to find a place in town. There was no rhyme or reason for that. So you can see why I am exhilarated by the positive changes that have occurred in my lifetime. Yes, we have not reached nirvana, but women face no totally closed doors and can aspire to be whatever their talents permit them to be. To illustrate, I will refer to my granddaughter, now a second-year law student. At age eight, she was with me when I was being filmed for something or other. She announced, "I'd like to be in the film too!" The director replied: "OK Clara, I'll ask you a question. What would you like to be when you grow up?" Clara answered without hesitation: "I'd like to be President of the United States of the World.” This is not an aspiration any eight-yearold girl would have had a generation before!

RRM: Precisely because it is important that more and more girls can aspire to be President of the United States of the World, there is a worldwide movement taking place, legislating gender quotas. Over eighty-five countries now have legislation to ensure the number of women in parliament. But not just in parliament. We see this 
gender quotas phenomenon gradually spreading to the executive, the judiciary, and in Europe, even to positions of governance in corporate boards of companies. The United States has not gone down that road. It has not even attempted, or seriously discussed, passing such legislation, even though women are still hugely underrepresented, when it comes to their presence in the House of Representatives, the Senate, and corporate boards. Given that you are one of the few justices who actually thinks that US justices and scholars can also learn from, and not only teach the world, might it be in order for the United States to consider joining other countries in passing gender quotas legislation? And, if so, how do you think it would fit with the constitutional framing of your country?

RBG: I do not think that in Europe, or in any other place, a court has mandated "quotas" or "parity." This has to be done by the government, as it was in France. It has to be done through legislation. Do I think there is a chance that this US Congress would pass such a legislation?

Before I answer, let me tell you of two cases. One involves the high school my colleague Stephen Breyer attended in San Francisco. It was a public high school for gifted children. There was an admission test. Students with the top scores were admitted. For a couple of years, more girls were admitted than boys. The school was concerned about that, so a quota was introduced - at least 50 percent of the admittees had to be boys. The American Civil Liberties Union successfully challenged the quota as unconstitutional. The other case arose in the State of Washington. The State adopted a law specifying: "The State committee of each major political party shall consist of one committee man, and one committee woman, from each county, elected at the county committee's organizational meeting. It shall have a chair, and a vice-chair, who must be of the opposite sex." That law was challenged as a violation of the equal protection principle. The case was finally decided by the Supreme Court of the State of Washington. That court upheld the parity system as ensuring women actual equality of rights. In the United States, because we are a federal system, measures can be tested in one state, and if they work, perhaps other states will adopt them. I can say, with a fair degree of confidence, that the Congress we now have would never pass such a measure. But at least it was passed by a state legislature and upheld by the highest court of that state.

RRM: But things are changing. It is maybe the case that we will soon have, not a woman President of the World, but maybe a woman President of the United States. If that were the case, are there, in your view, any prospects of gender quotas being legislated, or do you see it as too deeply in tension with the US constitutional culture?

RBG: I can't predict such a development. Perhaps in time it won't be necessary. Yes, our Congress does not have nearly the number of women it should. But when I became a justice, there were only six women in the Senate. Women at the Court and women in the Senate meet once a year for dinner, and we alternate the host. From just six women Senators at the first dinner, now there are close to twenty. So movement is in the right 
direction, though maybe not fast enough - twenty is far from fifty, but it is a lot better than six. A woman, Nancy Pelosi, recently was the Speaker of the House of Representatives. Now she is the Minority Leader. Whether legislation is needed remains to be seen.

RRM: We did start late, so I think we can take a little extra time. This will allow us to have twenty-five minutes of questions from the audience. Who would like to start and break the ice?

[a female student raises her hand]

RBG: Oh, this is wonderful. Let me tell you a story: My husband was a law school teacher and when he called for a volunteer, invariably the men's hands would go up first. A colleague advised him not to call on the first hand raised. "Wait a few seconds, and then a woman will raise her hand." The idea was that the man would speak from the top of his head; a woman would think before she spoke. So, I am very glad it is a young woman who asks the first question, and I suspect she has thought it out.

Question 1: Hello, I am a second-year researcher here at the EUI. Now, we talked quite a bit about your important role as a role model for us as young women today. I was wondering who the strong(er) or important women in your life were. Or whether you missed having an important role model for yourself.

RBG: One "role model” was a fictional character. She was Nancy Drew. Nancy Drew was the dominant person in her relationship with her boyfriend. She was a doer. She did not fit the description in a familiar verse: "What are little girls made of? Sugar and spice, and everything nice." And little boys: "Snails and nails, and puppy dogs' tails." Granted, Nancy Drew was not great or even good literature. And there was a real woman, Amelia Earhart, an airplane pilot. On the bench, I did not know of any woman judge in my growing-up years. But in 1980, I had the good fortune to meet the first woman ever appointed to a federal district-court judgeship. Her name was Burnita Shelton Matthews. She was appointed by President Truman in 1948 to the US District Court for the District of Columbia. She was a woman from Mississippi. When I was appointed to the US Court of Appeals for the District of Columbia Circuit in 1980, she was still alive, well into her nineties. She told me some of her experiences in the not-so-good-old days. She attended law school at night, and participated in suffragist activities. She joined marches and stood in front of the White House holding up her sign: "Votes for women." If the police confronted her, she remained silent. She did not say a word because she did not want to be arrested, which might have caused problems when she applied for admission to the bar. When she took her seat on the bench, she hired only women as law clerks. Why? Because her colleagues hired no women. I am told she had the best law clerks. Judge Matthews was responsible for the admission of the first African-American man to the bar of the District Court. She was a slender woman, about my height. She spoke with a southern accent and wore a lace collar and cuffs on the bench. Some people described her appearance as very feminine. 
But she was a woman of steel. Had I known about her in the 1940s, she would have been a role model for me.

Question 2: At a similar event in the United States, you expressed that your biggest disappointment was the outcome of Citizens United. ${ }^{12}$ I wonder whether you still hold that view and what the long term consequences of that judgment will be.

RBG: Citizens United held that capping the amount corporations can spend on political campaigns violates the First Amendment's freedom of speech guarantee. It was a five-to-four decision. I was a dissenter (along with Justice Stevens, who authored the dissent, Justice Sotomayor, and Justice Breyer). Sooner or later, I believe, the Court will see the error into which it has fallen and overrule the decision. It won't be tomorrow, it won't be next year, but eventually, I am confident, the Court will get it right.

The Supreme Court has made some dreadful mistakes: think of the Dred Scott decision, ${ }^{13}$ the most deplorable judgment ever rendered by the Court. The case involved a master, who took his slave into a free state. The slave's view: "Now I am in the State of Missouri. Here, I am a free man!” The Supreme Court's decision was startlingly broad. The Chief Justice, Roger Taney, declared in his opinion that no person brought to the United States from Africa in chains, and no descendent of such a person, shall ever qualify as a citizen. A Civil War overturned that decision. Plessy v. Ferguson, ${ }^{14}$ announcing the "separate but equal" doctrine, was another terribly wrong decision that is now essentially overruled. Recall, too, the Supreme Court decision upholding the detention of Japanese Americans during World War II. ${ }^{15}$ Although the war was over when the case came to the Court, the judgment affirmed what the Executive had done. That wrong decision was eventually righted, but not by the Court itself. The President formally apologized for the internment, and Congress passed a reparations bill providing compensation to people who had been detained or their descendants. A wise Supreme Court justice famously observed: "The Supreme Court is not final because it is infallible, but it is infallible only because it is final." ${ }^{16}$ We speak the last word.

Free speech law developed in the United States largely after World War I. The development started with two dissenting opinions written by Justice Holmes and joined by Justice Brandeis. ${ }^{17}$ Those dissenting opinions are now the law of the land. That is why I prize the opportunity to dissent when I think the Court has gotten it seriously wrong. Many systems, I know, do not permit dissenting opinions. That is true, for example, of the European Court of Justice. One view is that dissenting opinions dangerously convey to the public the impression that the law is uncertain, unstable. But I am glad

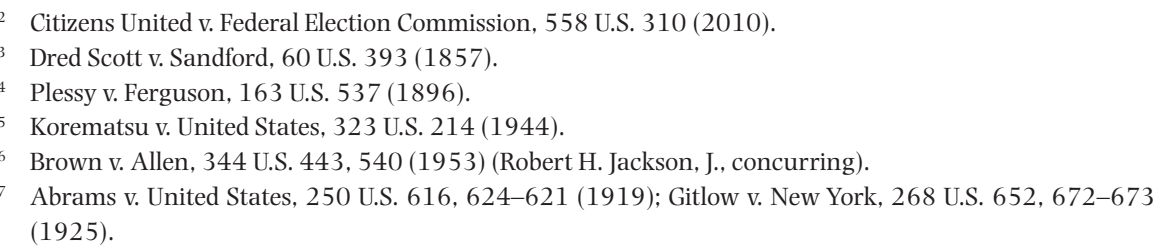


I can speak in dissent. And sometimes a dissent elicits an immediate reaction. That can occur on questions of statutory interpretation.

Question 3: Can you provide us with a concrete example of what you mean when you say that sometimes you can get an immediate reaction?

RBG: My favorite example is Lilly Ledbetter's case. ${ }^{18}$ Ledbetter worked as an area manager for the Goodyear Tire Company, a job filled overwhelmingly by men. Lilly had been working for the company for many years. One day, someone put in her mailbox a slip of paper with a series of numbers. The numbers revealed the pay the men who worked as area managers received. The most junior man was earning more than Ledbetter earned. She consulted a lawyer and brought a lawsuit under a statute called Title VII, which bans, nationwide, discrimination in employment on the basis of race, national origin, religion, and sex. The case was tried to a jury and Ledbetter won a substantial verdict. But the Supreme Court overturned that verdict, holding that Ledbetter had sued too late. Title VII says you must complain within 180 days of the discriminatory incident and Ledbetter, the Court reasoned, was way out of time. My view, expressed in a dissenting opinion, was that each pay check perpetuated the pay discrimination Ledbetter experienced, so she had 180 days from her most recent paycheck to sue. The dissent observed that, if you are the first woman doing a job that, until then, had been done only by men, you do not want to be seen as a complainer, you do not want to rock the boat. If Ledbetter had sued early on, no doubt the defense would have been "The pay differential has nothing to do with Lilly being a woman. She just doesn't do the job as well as the men." But after she had worked at the Goodyear plant for more than a decade, and had received good performance ratings, the employer can no longer defend on the ground that she doesn't do the job as well as her better-paid co-workers. So she had a winnable case. But, the Supreme Court ruled, she sued too late. The bottom line of my dissenting opinion was to this effect: "The ball is now in Congress' court to correct the error into which my colleagues have fallen.” The Court's wrong decision had engaged the public abroad as well as in the United States. Within two years, Congress passed the Lilly Ledbetter Fair Pay Act adopting the paycheck rule advanced in my dissenting opinion. It was the first law President Obama signed when he took office.

Question 4: I think you have beautifully evoked the solidarity between women that can exist exemplified in your career. But I am just wondering now, when more and more women ascend to an elite position, and therefore are somehow complicit in the oppression of those women at the very bottom. To what extent can solidarity between women exist today?

RBG: I hope the endeavor to achieve equal citizenship stature and access to justice for all women is reviving in the current generation. In my time as an equal rights advocate, the 1970s, the women's movement was coming alive all over the world, in

18 Lilly Ledbetter v. Goodyear Tire and Rubber Co., 550 U.S. 618 (2007). 
some places to a greater extent than in others. Just one example: The UN had declared International Women's Year. Solidarity, being part of a movement to elevate the status of all women, was prominent in the 1970s. Now, it seems to me, young women of my granddaughter's generation are fired up. More so than the generation immediately preceding theirs. And they will care about the welfare of women suffering the greatest oppression. At least this is my hope.

QuesTion 5: I was wondering, as the Lilly Ledbetter case was mentioned, if you think that any of your other dissents will have an impact on the legal, or legislative, developments in the future.

RBG: A dissent mentioned before, in Shelby County, called public attention to the grave mistake the Court made. We can see it now. Some states, in the wake of the Court's decision, have restricted access to the polls by requiring voter ID cards, shortening the hours in which people can exercise the franchise, closing polling stations on weekends, and erecting other barriers. Those devices did not survive preclearance when the 1965 Voting Rights Act was in force. Under that Act, states that had a history of disenfranchising African Americans could not make any change in their voting laws without gaining the approval either of the Department of Justice, or of a three-judge District Court in the District of Columbia. Preclearance was an effective check on state attempts to curtail voting by African Americans. Once that check was invalidated, laws that the Department of Justice had previously turned down reappeared. There is no way to stop their reappearance, short of an arduous and long litigation process. That's where we are now.

I also hope my dissenting opinion in the Hobby Lobby case will eventually become the prevailing view. ${ }^{19}$ That case was commenced by a company whose owners had deep religious convictions against certain kinds of contraception. The company, which had a large workforce, refused to cover those contraceptive devices in its group health insurance plan. No one questioned the sincerity of the owners' religious beliefs, but the workforce included many women who did not share the owners' views on contraception. The law appeared to say that those women were entitled to have contraceptive coverage. The Court held that the employer's religious freedom had to be respected, therefore the company did not have to provide the resisted contraceptive coverage. I think it was a wrong decision. Hobby Lobby's owners have every right in the world to keep the government from intruding on their religious beliefs and practices. But they have no right to force their beliefs on people who do not share them.

Question 6: Maybe you could also share with us your favorite opinion on gender equality during your time at the Court.

RBG: Most people would probably say my opinion in the Virginia Military Institute case $^{20}$ VMI is a state institution, and it is a military institution, although only 15

19 Burwell v. Hobby Lobby Stores, Inc., 134 S. Ct. 2751 (2014).

20 United States v. Virginia, 518 U.S. 515 (1996). 
percent of the graduates pursue careers in the military. Most graduates engage in business enterprises. The State of Virginia did nothing to provide women with an equivalent opportunity. The Court's ruling gave the State of Virginia a choice: either admit qualified women, or close the school. The faculty at VMI favored admission of women. By doing so, VMI could upgrade the caliber of its student body. Another significant feature of the litigation: The plaintiff was not a young woman who had been denied admission. The suitor was the US government seeking to hold the State to the Constitution's Equal Protection guarantee. It wasn't that many years before the VMI litigation that the US military academies-West Point, Annapolis, the Air Force Academy - admitted no women. Midway through litigation against those institutions, the government decided to switch its position. It began admitting women to the academies. By the time of the VMI case, women had been attending the US military academies for over ten years. That good experience made VMI an easy case.

One of my favorite majority opinions is in a case not that well known. It is called M.L.B. ${ }^{21}$ The petitioner in the Supreme Court was a woman charged with being a neglectful parent. The proceeding was one to deprive her permanently of any parental rights. She lost in the court of first instance. In order to appeal, she had to purchase a transcript of the first instance proceeding. She lacked the money to do that. The case was typed civil, not criminal. The State is obliged to provide for legal assistance only in criminal cases, not in civil cases. The opinion I wrote for the Court's majority explains that the line separating civil cases from criminal cases is not that clear. Though characterized as a civil matter, depriving a mother of her parental status can be far more devastating than, say, a week in jail. The Court's majority comprehended that denying the woman's appeal because she could not pay for the transcript deprived her of both equal protection and due process.

QuesTION 7: When people ask me what I do at the EUI, I sometimes answer that I write a Ph.D. in law, other times that I write a Ph.D. in feminist legal theory. Depending on the context, the word feminist is sometimes controversial and sometimes fashionable. I have not heard you use that word to describe yourself so I would like to know whether you consider yourself a feminist.

RBG: If you have not heard it, you will hear it now. I am a feminist! It is true, in the United States, in some quarters, feminism is considered the F-word. But what does it mean to be a feminist, really? It means you believe that society should encompass and embrace all people, women as well as men; that women should have a fair chance to do whatever their God-given talents enable them to do and that they should not be held back by artificial barriers. What is objectionable about that? Most men I know would count themselves feminists. Certainly my spouse did.

RRM: Maybe, I will ask you the last question then. As our researchers move on in making choices about their lives and careers, what would be one single and most precious piece of advice you would want to share with them? 
RBG: A single piece of advice? I can convey that in my own life, I have gotten tremendous satisfaction from doing things I was not paid to do. If you are a professional of any kind, you have an obligation to try to make things better in your community. If you have a passion about an issue-whether it is combating racism or ending sexbased discrimination, or preserving the environment - whatever it is, you should pursue that passion in addition to your paid work. Do something to help repair tears in your local community, nation, or world, something that will make life a little better for people less fortunate than you.

RRM: Thank you so much. 